\title{
The Impact of the COVID-19 Pandemic on the Budget Performance of the Kediri City Government
}

\author{
M. Anas ${ }^{1}$, Linawati $^{2}$, Eunike Rose Mita Lukiani ${ }^{3}$ \\ ${ }^{1}$ Departement of Masters of Economic Education, ${ }^{2}$ Department of Accounting, \\ ${ }^{3}$ Department of Economic Education, University of Nusantara PGRI Kediri, Kediri, Indonesia \\ Corresponding Author: M. Anas
}

DOI: https://doi.org/10.52403/ijrr.20220148

\begin{abstract}
This study aims to analyze the impact of the Covid-19 pandemic on the performance of the Kediri City Government's budget (APBD), including: 1) analysis of regional revenue performance, 2) analysis of regional expenditure performance, with several elements of analysis for each type of performance analysis, and 3) performance analysis. Financing, so that the results of this analysis provide an overview related to the posture and performance of the budget and are expected to be a reference for the Kediri City Government in determining policies, especially the economic sector. Quantitative descriptive methods were used in this study to describe phenomena with data processing systems that were already available in the form of numbers that describe the Kediri City Government APBD. The analysis of research data used in this study was in the form of financial ratios sourced from the Kediri City Government Financial Statements for three years before the Covid-19 Pandemic (20172019) and at the moment the Covid-19 Pandemic (in 2020) occurred. The results of data analysis show that: (1) the performance of the revenue budget is categorized good, because the realization of income exceeds the set target. In 2020, although the realization of revenue could exceed the target, the percentage of revenue decreased compared to previous years, (2) as a impact of the Covid-19 Pandemic, the revenue of the City of Kediri in the 2020 fiscal year experienced a negative growth of $-4.2 \%$, (3) the budget performance of the Kediri City Government from 2017 to 2020 in the aspect of financial independence was categorized very low, (4) the realization of regional tax revenues
\end{abstract}

and regional levies exceeds the targets set in APBD, and the performance of the Kediri City Government in the aspect of the effectiveness of local tax collection and regional levies were in the very effective category, (5) the performance of the Kediri City Government in collecting revenue in the form of regional taxes and regional levies was categorized efficient, (6) in the 2020 fiscal year, when the Covid-19 Pandemic occurs, the absorption of the Kediri City Government's budget was the lowest compared to previous years, (7) the 2020 budget year the growth of the Kediri City Government expenditure grew minus $8.00 \%$ ($8.00 \%$ ) compared to the previous year, (8) the performance of the Kediri City Government in terms of spending efficiency for the last four years, from 2017 to 2020 has shown an efficient performance, (9) the Government of Kediri City allocates the budget in its APBD mostly for indirect expenditure (an average of 55\%), which consists of personnel expenditure, grants, and social assistance, and the rest were allocated for direct expenditures (an average of $45 \%$ ) which consists of goods and services expenditures, and capital expenditures, (10) SiLPA for the 2020 fiscal year has increased by $11 \%$ from the previous year's of SiLPA.

Keywords: Covid-19 Pandemic, Budget Performance, Revenue, Expenditure, Financing

\section{INTRODUCTION}

The Corona Virus Disease 19 (Covid-19) pandemic was a phenomenal event that occurred at the end of 2019. This phenomenon has become the attention of the global community because it has infected 
humans in every country all around the world, including Indonesia. The Covid-19 pandemic has had an impact on all sectors of life, including the economy. Efforts made by the government were to take policies to overcome and control the spread of the virus, one of which is through social distancing policies to Large-Scale Social Restrictions (PSBB). The impact of the implementation of this policy was very influential on the economic sector. For the 2020 fiscal year, state revenues experienced a very deep contraction while state expenditures increased very high. Realization of state revenues was IDR $1,647.7$ trillion or $96.9 \%$ of the revenue budget in the 2020 APBN. Compared to 2019, state revenues in 2020 decreased by IDR 312.8 trillion or $15.9 \%$. On the expenditure side, in the 2020 APBN, the realization of state expenditures reached IDR 2,595.4 trillion or $94.7 \%$, consisting of central government expenditures of IDR $1,832.9$ trillion, and transfers to regions and village funds of IDR 762.5 trillion. Realization of state expenditures in 2020 increased by IDR 286.1 trillion or $12.3 \%$ compared to state expenditures in 2019. Based on the realization of these revenues and expenditures, the 2020 State Budget experienced a deficit of IDR 947.6 trillion as a result of a temporary decline in total revenues. Expenditure was increasing. The amount of the deficit reached more than $6 \%$ of Gross Domestic Product (GDP). To cover the deficit, the government made a net financing of IDR 1,193.2 trillion, which came from domestic financing of $\mathrm{Rp} 1,46.8$ trillion and foreign financing of $\mathrm{Rp} 46.4$ trillion. Thus, in the 2020 fiscal year, there was an excess of budget financing (SILPA) of IDR 245.6 trillion.

The Covid-19 pandemic not only gave an impact on the country's economy but also has an impact on regional financial management, including the Kediri City Government. The issuance of local regulation Number 1 of 2020 concerning State Financial Policy and Financial System Stability for Handling the Covid-19
Pandemic and Presidential Instruction of Republic of Indonesia (Inpres) Number 4 of 2020 regarding refocusing of activities, budget relocation, and accelerating the process of procuring goods and services to deal with COVID-19 made the juridical basis as the basis for policy making for the central government and local governments, including the Kediri City Government in implementing budget refocusing and relocation policies. Unexpected Budget increased by $842.93 \%$, while social assistance funds also increased by $300.29 \%$.

The implementation of this budget change created its own problems for local governments (Pemda). The Mayor of Kediri Regulation Number 24 of 2020 states that several problems related to regional financial management as a result of the implementation of the policy of refocusing and relocating the budget include: inadequate budgets, regulations that are insistent, traumatic for regional heads in BTT management, and this has never happened before and disasters that have a national and even international impact such as the Covid-19 pandemic [1].

The Kediri City Government also impacted by the Covid-19 Pandemic requires an adjustment of the Regional Revenue and Expenditure Budget (APBD) for Fiscal Year 2020. The adjustment of the Kediri City APBD for Fiscal Year 2020 was conducted based on the Kediri City Regional Regulation (Perda) Number 2 of 2020 concerning Changes to the Regional Budget of 2020 Fiscal Year 2. Budget revenue for 2020, which was originally IDR 1.239 trillion, was reduced by IDR 31.312 billion to IDR 1.208 trillion. The 2020 budget of IDR 1.425 trillion increased by IDR 50.279 billion to IDR 1.475 trillion. The 2020 budget deficit after the amendment was set to be IDR 267.340 billion. Meanwhile, net financing increased by IDR 81.491 billion to become IDR 267.340 billion [2]

Based on the previous explanation, this study aims to analyze the impact of the Covid-19 pandemic on the budget 
performance (APBD) of the Kediri City Government, including: 1) analysis of regional revenue performance, 2) analysis of regional expenditure performance, with several elements of analysis for each type of performance analysis, and 3 ) Analysis of financing performance, so that the results of this analysis provide an overview related to the position and performance of the budget and are expected to be used as information for the Kediri City Government in determining policies, especially the economic sector.

Research in the field of public sector accounting with regional financial studies has been widely conducted by previous researchers, both through quantitative approaches as conducted by [3], [4], and [5] and qualitatively as conducted by [6] and [7]. In contrast to previous research, this study uses a qualitative approach with a comprehensive quantitative descriptive analysis of the financial statements of the local government of Kediri City during the Covid-19 pandemic. With this analysis, a clear and comprehensive picture of the budget performance of the Kediri City Government will be obtained. This study specifically analyzes the impact of the Covid-19 pandemic on the budget performance of the Kediri City Government comprehensively, both in terms of income and expenditure aspects as well as financing aspects for various sectors in the APBD. (5)

\section{LITERATURE REVIEW}

\section{A. Public Sector Accounting}

Public sector accounting [8] is an accounting technique and analysis mechanism that is implemented in the management of public funds by entities that have the function of providing services to the community (non-profit oriented), such as central and local government agencies, departments/ministries, social institutions, religious institutions, educational institutions, NGOs, and public sector cooperation projects.

\section{B. Regional Finance}

Regional finance according to [9] is a process of identifying, measuring, recording, and reporting economic (financial) transactions by local government entities, both provincial, city, and district governments that can provide information in the context of making economic decisions by stakeholders who need it.

Regional financial management is the overall activity of local government, which includes: planning, implementation, administration, reporting, and accountability, as well as regional supervision. Regional financial management involves several managements like general management called administrative management and special management called treasurer.

Performance is a multidimensional construct consisting of various factors that affect the public sector, which is important for any activity carried out by an entity. The purpose of measuring performance in public sector entities is to improve people's lives by providing the best service. Public sector performance measurement includes the activity of determining a series of performance measures or indicators that describe information so that it is possible for work units in the public sector to monitor their performance in producing outputs and outcomes for the community.

\section{Regional Revenue and Expenditure Budget (APBD)}

APBD is a regional government financial operational plan, which is functioned to describing estimated expenditures to finance regional activities and projects within a year, also describes estimated revenues and sources of revenue to finance or cover expenses in the context of implementing the function of local government is service to the community [10].

Government Accounting Standards (SAP) defines the budget as a guideline for actions to be taken by the government, including plans for: revenues, expenditures, 
transfers, and financing which are measured in Rupiah. The budget is arranged according to certain classifications systematically for a certain period [11].

Budget performance according to [12] is a description of the achievement of the implementation of an activity/program/ policy in realizing the goals, objectives, mission, and vision of the entity. The performance indicators are quantitative and qualitative measures that describe the level of achievement of an entity's goals or objectives that have been set, taking into account the indicators of input (input), output (output), results, benefits, and impacts. According to [13], budget performance analysis can be completed in two parts, including: 1) Revenue performance analysis, and 2) Spending performance analysis.

\section{C.1. Revenue Performance Analysis}

Analysis of regional revenue performance is conducted by comparing the realization of revenue with the budget. According to [14], if the realization exceeds the budget (target), then the performance of the local government budget on the revenue aspect is categorized as good. Based on the information in the Budget Realization Report (LRA), regional revenue analysis can be conducted in several ways, including:

a. Analysis of Variance (difference) of Revenue Budget. This analysis is conducted by calculating the difference between the actual revenue and the budgeted one.

b. Income Growth Analysis. To find out whether the local government is in the current budget year or over several budget periods. The formula is as follows:

$$
\text { Growth of PAD Year } t=\frac{\text { PAD yeart }- \text { PAD yeart } t-1}{\text { PAD yeart }} \times 100 \%
$$

c. Financial Ratio Analysis. It is used as a basis for knowing the financial performance of an entity. This ratio is a way of comparing various financial data APBD financial ratios consist of:

1. Regional Financial Autonomy Ratio. Demonstrate the ability of local governments to self-finance government activities, development, and services to people who have paid taxes and levies as a source of revenue needed by the region. the formula is: [9]

Financial autonomy $=\frac{P A D}{\text { Total income }} \times 100 \%$

2. Effectiveness and Efficiency Ratio of Regional Taxes. The effectiveness ratio shows the ability of the region to realize the budgeted regional tax compared to the target that has been set based on the real potential of the region. Formula is: [9]

Effectiveness Ratio $=\frac{\text { Local Tax Realization }}{\text { Local Tax Target }} \times 100 \%$

The efficiency ratio describes the comparison between the amount of costs incurred by the local government in order to obtain revenue with the realization of the income received [9].

Efficiency Ratio $=\frac{\text { LocalTax CollectionFas }}{\text { Local Tax Realization }} \times 100 \%$

\section{C.2. Expenditure Performance Analysis}

Expenditure performance analysis is functioned for evaluating whether local governments have used APBD economically, efficiently, and effectively (value of money). According to [15] the performance of the regional budget is considered good if the realization is lower than the budgeted amount, which is an indicator of budget efficiency. However, in terms of regional expenditures, it is also important to analyze the compatibility of spending because this is related to the function of the budget as a means of distribution, allocation, and stabilization.

a. Expenditure Variance Analysis. This analysis is the difference or difference between the actual expenditure and the 
budget. Expenditure variance analysis is calculated based on the following formula:

\section{Expenditure Variance $=$ Actual Expenditure - Budget}

b. Growth Analysis. Expenditure growth analysis is used for knowing the growth of spending from year to year. The development of the spending growth will appear positive or negative.

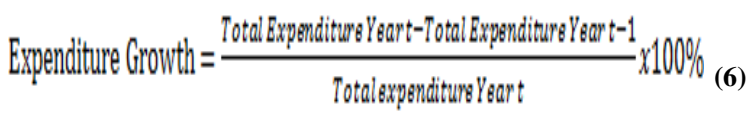

c. Expenditure Efficiency Analysis. This analysis is used to measure the level of budget savings made by the government. According to [9] if the efficiency ratio shows a result lesser than $100 \%$ then there has been a budget savings (efficiency), and in reverse if the resulting ratio shows a number above $100 \%$ then there is budget wastage (inefficiency). The formula for calculating expenditure efficiency is as follows:

Expenditure Efficiency $=\frac{\text { Expenditure Realization }}{\text { Budget }} \times 100 \%$

d. Expenditure Compatibility Analysis. The expenditure compatibility ratio shows how local governments prioritize budget policies in allocating regional expenditures to finance development (directly) and optimally finance routine (indirect) expenditures. The formula for calculating the direct expenditure ratio is as follows:

Direct Expenditure Ratio $=\frac{\text { Total Direct Expenditurs }}{\text { TotalExpenditurs }} \times 100 \%$

The formula used to calculate the indirect expenditure ratio is as follows:

Indirect Expenditure Ratio $=\frac{\text { Total lndirect Expenditure }}{\text { Total Expenditure }} \times 100 \%$

\section{C.3. Financing Analysis}

It is useful for knowing local government budget patterns. In addition, it can also be used to comprehend local government budget policies. One of the posts considered urgent in the analysis of financing is the budget surplus of Budget Financing (SILPA).

Research in the field of public sector accounting with regional financial studies has been widely conducted by previous researchers, both through quantitative approaches as conducted by [3], [4], and [5] and qualitatively by [6] and [7]. In contrast to previous research, this study uses a qualitative approach with a comprehensive quantitative descriptive analysis of the financial statements of the local government of Kediri City during the Covid-19 pandemic. With this analysis, a clear and comprehensive picture of the budget performance of the Kediri City Government will be obtained.

\section{MATERIALS \& METHODS}

This study aims to analyze how the impact of Covid-19 on the budget performance of the Kediri City Government comprehensively, both in terms of income, expenditure aspects, and financing aspects for various posts in the APBD. In order to achieve these objectives in this study used a fairly simple method, namely quantitative descriptive [16]. Quantitative descriptive method is used in this study to describe phenomena with data processing systems that are already available in the form of numbers that describe certain situations and conditions in an entity or agency [17]. Assessment of the nature and existing conditions required the processing of research data. Thus, in line with the research objectives that have been stated previously, this method will be able to support the research objectives in the form of a descriptive analysis of the impact of the Covid-19 pandemic on the budget performance of the Kediri City Government.

Analysis of research data used in this study in the form of financial ratios sourced 
from the Kediri City Government Financial Statements. The measurement of the level of financial independence is used the criteria in table 1 below:

Table 1: Criteria of Regional Financial Independence

\begin{tabular}{|c|c|}
\hline Independence Criteria & Independence Ratio (\%) \\
\hline Very Low & $0-25$ \\
\hline Low & $>25-50$ \\
\hline Medium & $>50-75$ \\
\hline High & $>75-100$ \\
\hline \multicolumn{2}{|}{ Source: $[18]$}
\end{tabular}

An analysis that describes the effectiveness of local revenue collection originating from regional taxes and levies, the level of effectiveness is measured by the criteria in Table 2.

Table 2: Criteria for effectiveness of regional taxes and regional levies

\begin{tabular}{|c|c|}
\hline Criteria & Effectiveness Ratio (\%) \\
\hline Very effective & $>100$ \\
\hline Effective & $>90-100$ \\
\hline Fairly Effective & $>80-90$ \\
\hline Less effective & $70-80$ \\
\hline Ineffective & $<70$ \\
\hline
\end{tabular}

The compatibility analysis consisting of the capital expenditure ratio and the operational expenditure ratio shows the local government's policy in allocating the budget to APBD. According to [9] ideally there is no definite standard regarding the ratio of capital expenditures and operational expenditure ratios in APBD, this is strongly influenced by the dynamics of development activities and the amount of investment needed to achieve economic growth that has been targeted by each local government.

\section{RESULT}

The revenue budget variance is calculated by the difference between the realized revenue and the budgeted. Typically, this budget difference is seen in the budget realization report that has been presented by the entity (local government). Table 1 shows the amount of revenue budgeted in the Kediri City APBD and the realization of the revenue budget for 2017 to 2020. (20)

Table 3: Budget and Realization of Kediri City Government Revenue in 2017-2020 (in Millions of Rupiah)

\begin{tabular}{|c|c|c|c|c|c|}
\hline Year & Budget & Realization & Difference & Growth \\
\cline { 4 - 6 } & & & IDR & \% & $(\boldsymbol{\%})$ \\
\hline $\mathbf{2 0 1 7}$ & 1.152 .340 .169 .255 & 1.239 .131 .382 .634 & 86.791 .213 .379 & 107,53 & \\
\hline $\mathbf{2 0 1 8}$ & 1.130 .510 .377 .625 & 1.278 .488 .601 .892 & 147.978 .224 .267 & 113,09 & 0,03 \\
\hline $\mathbf{2 0 1 9}$ & 1.139 .350 .356 .230 & 1.339 .405 .675 .037 & 200.055 .318 .807 & 117,56 & 0,05 \\
\hline $\mathbf{2 0 2 0}$ & 1.238 .777 .400 .869 & 1.283 .093 .769 .233 & 44.316 .368 .364 & 103,58 & $-4,20$ \\
\hline \multicolumn{7}{|c|}{ Source: Research data processed }
\end{tabular}

Data on Regional Original Revenue of the Kediri City Government from 2017 to 2020 is presented in table 4 below.

Table 4: Budget and PAD Realization of the Regional Government of Kediri City in 2017-2020

\begin{tabular}{|c|c|c|c|c|c|}
\hline \multirow{2}{*}{ Year } & Budget & Realization & \multicolumn{2}{|c|}{ Difference } & \multirow{2}{*}{ Growth (\%) } \\
\cline { 3 - 5 } & & & IDR & \% & \\
\hline $\mathbf{2 0 1 7}$ & 202.308 .331 .248 & 293.065 .134 .149 & 90.756 .802 .901 & 144,86 & \\
\hline $\mathbf{2 0 1 8}$ & 225.912 .159 .759 & 249.093 .229 .532 & 23.181 .069 .773 & 110,26 & $-0,15$ \\
\hline $\mathbf{2 0 1 9}$ & 224.561 .778 .934 & 266.745 .042 .378 & 42.183 .263 .444 & 118,78 & 0,07 \\
\hline $\mathbf{2 0 2 0}$ & 251.282 .597 .849 & 262.886 .289 .227 & 11.603 .691 .378 & 104,62 & $-0,01$ \\
\hline \multicolumn{7}{|c}{ Source: Research data processed }
\end{tabular}

The Kediri City regional tax and levy revenue budget and its realization during 2017 to 2020 are shown in table 5 below.

Table 5: Budget and Realization of Regional Taxes and Levies for the City of Kediri in 2017-2020
\begin{tabular}{|c|c|c|c|c|c|}
\hline Year & Budget & Realization & Difference & Growth (\%) \\
\cline { 4 - 6 } & & & Rp & $\%$ & \\
\hline $\mathbf{2 0 1 7}$ & 85.673 .260 .663 & 121.958 .626 .476 & 36.285 .365 .813 & 142,35 & \\
\hline $\mathbf{2 0 1 8}$ & 96.248 .830 .000 & 111.775 .511 .059 & 15.526 .681 .059 & 116,13 & $-8,35$ \\
\hline $\mathbf{2 0 1 9}$ & 99.987 .626 .000 & 127.882 .916 .869 & 27.895 .290 .869 & 127,90 & 14,41 \\
\hline $\mathbf{2 0 2 0}$ & 114.765 .622 .400 & 122.497 .079 .939 & 7.732 .457 .539 & 106,74 & $-4,21$ \\
\hline
\end{tabular}


Table 6: Budget and Realization of Local Government Expenditures for the Kediri City in 2017-2020 (in Millions of Rupiah)

\begin{tabular}{|c|c|c|c|c|c|}
\hline Year & Budget & Realization & \multicolumn{2}{|c|}{ Difference } & Growth \\
\cline { 4 - 5 } & & & IDR & \% & $(\mathbf{\%})$ \\
\hline $\mathbf{2 0 1 7}$ & 1.343 .004 .503 .718 & 1.269 .944 .308 .580 & 73.060 .915 .138 & 94,56 & \\
\hline $\mathbf{2 0 1 8}$ & 1.286 .436 .587 .918 & 1.237 .745 .256 .863 & 48.691 .331 .055 & 96.22 & $-3,00$ \\
\hline $\mathbf{2 0 1 9}$ & 1.291 .791 .333 .600 & 1.312 .905 .390 .345 & -21.114 .056 .745 & 101.63 & 6,00 \\
\hline $\mathbf{2 0 2 0}$ & 1.424 .625 .920 .381 & 1.207 .691 .610 .980 & 216.934 .309 .401 & 84.77 & $-8,00$ \\
\hline \multicolumn{5}{|c}{ Source: Research data processed }
\end{tabular}

Table 6 shows the Kediri City Government's budget and its realization in the 2017 to 2020 fiscal year

Table 7: Direct Expenditures and Indirect Expenditures on Total Local Government Expenditures for the Kediri City in 2017 2020 (in Millions of Rupiah)

\begin{tabular}{|c|c|c|c|c|c|}
\hline \multirow{2}{*}{ Year } & Total Expenditure & \multicolumn{2}{|c|}{ Direct Expenditures } & \multicolumn{2}{c|}{ Indirect Expenditures } \\
\cline { 3 - 6 } & & Amount & Ratio & Amount & Ratio \\
\hline $\mathbf{2 0 1 7}$ & 1.269 .944 .308 .581 & 596.763 .989 .512 & 0,47 & 673.180 .319 .069 & 0,53 \\
\hline $\mathbf{2 0 1 8}$ & 1.237 .745 .256 .863 & 507.165 .270 .571 & 0,41 & 730.579 .986 .292 & 0,59 \\
\hline $\mathbf{2 0 1 9}$ & 1.312 .905 .390 .345 & 714.561 .995 .870 & 0,54 & 598.343 .394 .475 & 0,46 \\
\hline $\mathbf{2 0 2 0}$ & 1.207 .691 .610 .980 & 568.391 .299 .448 & 0,47 & 639.300 .311 .531 & 0,53 \\
\hline \multicolumn{5}{|c|}{ Source: Research data processed } \\
\hline
\end{tabular}

Data on the amount of direct expenditure and the amount of indirect expenditure in the Kediri City Government APBD for the 2017 to 2020 Fiscal Year are shown in table 7.

Table 8: Budget and Realization of Financing (SiLPA) of the Kediri City Government for the Year 2017-2020 (in Millions of Rupiah)

\begin{tabular}{|c|c|c|c|c|c|}
\hline \multirow{2}{*}{ Year } & Budget & Realization & \multicolumn{2}{|c|}{ Difference } & Growth \\
\cline { 4 - 6 } & & & $\mathbf{R p}$ & $\mathbf{\%}$ & $(\mathbf{\%})$ \\
\hline $\mathbf{2 0 1 7}$ & 210.664 .334 .463 & 230.907 .373 .861 & 20.243 .039 .938 & 110,00 & \\
\hline $\mathbf{2 0 1 8}$ & 165.926 .210 .293 & 200.094 .398 .906 & 34.168 .188 .613 & 120,59 & -13 \\
\hline $\mathbf{2 0 1 9}$ & 152.440 .977 .370 & 240.839 .243 .934 & 88.398 .266 .564 & 157,99 & 20 \\
\hline $\mathbf{2 0 2 0}$ & 185.848 .519 .511 & 267.341 .428 .526 & 81.492 .909 .014 & 143,85 & 11 \\
\hline \multicolumn{5}{|c}{ Source: Research data processed } \\
\hline
\end{tabular}

The leftovers of the Budget Calculation (SiLPA) during the 2017 to 2020 fiscal year, the Kediri City Government is presented in table 8 below.

\section{DISCUSSION}

\section{Analysis of variance (difference) of revenue budget}

Based on the calculation of the income variance as shown in table 3 , it can be seen that the revenue of the Kediri City Government from 2017 to 2019 showed good budget performance, since the realization of revenue receipts exceeded the budget and even experienced an increase in the number of revenues from year to year. In 2018, there was a variant of IDR $147,978,224,267$,-or $113.09 \%$. As well in 2019 , the realization of income was IDR $1,339,405,675,037$, - while the budgeted amount was IDR $1,139,350,356,230$, which means it could exceed the target of reaching IDR $200,055,318,807$, - or by $(117.56 \%)$. In 2020, the realization of income is also greater than the budget. The revenue budget for 2020 is set at IDR $1,238,777,400,869$, - while the realization reached IDR 1,283,769,233,- which means that the realization of income reached
$103.58 \%$. Although in 2020 the realization of revenue achieved by the Government of Kediri City exceeded the budget target, this increase was the lowest when compared to the increase in previous years. It can be concluded that the Covid-19 pandemic has had an impact on reducing the realization of the Kediri City Government's revenue budget.

\section{Revenue Growth Analysis}

Table 3 shows that before the Covid-19 Pandemic, the Kediri City Government's income increased from year to year (growing). Revenue in 2018 grew by $3 \%$ compared to the previous year. Even in 2019 revenue growth reached an increase of 5\% compared to 2018. In 2020 the realization of Kediri City Government revenue exceeded the budgeted amount. The 2020 revenue budget amounted to IDR $1,238,777,00,869$ while the realization of revenue reached IDR 1,283,093,769,233, thus exceeding the target of IDR 
44,316,368,364,-. However, this amount is lower when compared to the realization of revenue in 2019 of IDR 1,339,405,675,037, -, or in other words, as a result of the Covid-19 Pandemic, the revenue of the City of Kediri in the 2020 fiscal year experienced a negative growth of $-4,2 \%$.

\section{Financial independence analysis}

Table 9: Financial Independence of the Kediri City Government in 2017-2020

\begin{tabular}{|c|c|c|c|c|}
\hline Year & Total income & PAD & Ratio (\%) & Criteria \\
\hline $\mathbf{2 0 1 7}$ & 1.239 .131 .382 .634 & 293.065 .134 .149 & 24 & Very Low \\
\hline $\mathbf{2 0 1 8}$ & 1.278 .488 .601 .892 & 249.093 .229 .532 & 19 & Very Low \\
\hline $\mathbf{2 0 1 9}$ & 1.339 .405 .675 .037 & 266.745 .042 .378 & 20 & Very Low \\
\hline $\mathbf{2 0 2 0}$ & 1.283 .093 .769 .233 & 262.886 .289 .227 & 20 & Very Low \\
\hline
\end{tabular}

Table 9 shows that the budget performance of the Kediri City Government from 2017 to 2020 in the aspect of financial independence is categorized very low. The Kediri City Government's financial independence ratio in 2017 was $24 \%$, but in 2018 it fell to 19\%. In 2019 and 2020 the level of financial independence of the Kediri City Government has increased to $20 \%$. Overall, it can be concluded that the level of financial independence of the Kediri City Government is still very low. This level indicates that the pattern of the Kediri City Government's financial relationship with the Central Government is instructive, means that the central government still has a dominant role in its contribution to regional finance. In other
Table 9 demonstrates the ability of local governments to self-finance government activities, development, and services to people who have paid taxes and levies as a source of revenue needed by the region. Based on the independence criteria as presented in table 1 , the level of financial independence of the Kediri City Government in 2017-2020 is shown in table 9 below:

\section{Analysis of the effectiveness of local taxes and local levies}

Table 10: Effectiveness of Regional Taxes and levies for the City of Kediri in 2017-2020

\begin{tabular}{|c|c|c|c|c|}
\hline Year & Target & Realization & Ratio (\%) & Criteria \\
\hline $\mathbf{2 0 1 7}$ & 85.673 .260 .663 & 121.958 .626 .476 & 142,35 & Very Effective \\
\hline $\mathbf{2 0 1 8}$ & 96.248 .830 .000 & 111.775 .511 .059 & 116,13 & Very Effective \\
\hline $\mathbf{2 0 1 9}$ & 99.987 .626 .000 & 127.882 .916 .869 & 127,90 & Very Effective \\
\hline $\mathbf{2 0 2 0}$ & 114.765 .622 .400 & 122.497 .079 .939 & 106,74 & Very Effective \\
\hline
\end{tabular}

Table 10 shows that the realization of regional tax and retribution revenues exceeds the target set in APBD. In 2017, the target for local taxes and levies was set at IDR $85,673,260,663$, and the realization was IDR $121,958,626,476$, or $2.35 \%$. In 2018 total regional tax and levies revenues reached $116.13 \%$ and experienced a significant increase in 2019 where the revenue realization ratio reached $127 \%$. In words, from a financial perspective, the Kediri City Government has not been able to implement regional autonomy more independently. The size of the independence ratio is inversely proportional to the level of dependence of the local government on the provincial government and/or the central government. The lower ratio of local government financial independence, the higher level of dependence on external parties, like the provincial government and/or the central government [9]. The financial dependence of the Kediri City Government on the Central Government is still very high, especially related to central government support in the form of the General Allocation Fund (DAU).
2020, the target for local taxes and levies for Kediri City is set at IDR $114,765,622,400$, - and the target can be exceeded, the realization of which will be IDR $122,497,079,939$, - or $106.74 \%$. Although in 2020 the ratio of regional tax revenues and regional levies reached $106.74 \%$, the level of achievement of realization is the lowest compared to previous years. 
Efficiency Analysis of regional taxes and regional levies

Table 11: Efficiency of Regional Taxes and Levies for the City of Kediri in 2017-2020

\begin{tabular}{|c|c|c|c|c|}
\hline Year & Cost & Realization & Ratio (\%) & Criteria \\
\hline $\mathbf{2 0 1 7}$ & 82.186 .223 .245 & 121.958 .626 .476 & 67,39 & efficient \\
\hline $\mathbf{2 0 1 8}$ & 61.657 .753 .873 & 111.775 .511 .059 & 55,16 & efficient \\
\hline $\mathbf{2 0 1 9}$ & 81.970 .765 .413 & 127.882 .916 .869 & 64,10 & efficient \\
\hline $\mathbf{2 0 2 0}$ & 85.576 .375 .824 & 122.497 .079 .939 & 69,86 & efficient \\
\hline
\end{tabular}

The performance of the Kediri City Government in collecting revenue in the form of regional taxes and regional levies is categorized as efficient. The smaller the efficiency ratio means that the government's performance in collecting local taxes and regional levies is getting better. Therefore, the local government needs to carefully calculate the amount of costs incurred to realize the receipt of all the revenue it receives so that it can be seen whether the revenue collection activities to be received are efficient or not. It is important for local governments to do this because even though local governments have succeeded in realizing revenue receipts according to or even exceeding the set targets, this success has no meaning if it turns out that the costs incurred to realize the revenue targets are greater than the realization of the revenues they receive.

\section{Expenditure Variance Analysis}

The expenditure variance as shown in table 6 shows the performance of the Kediri City Government from 2017 to 2020 showing good indicators. In the 2017 fiscal year, the Kediri City Government succeeded in absorbing $94.56 \%$ of the total budgeted expenditure. The absorption of the budget for the 2018 fiscal year has increased compared to the previous year, where this year the Kediri City Government has used an expenditure budget of $96.22 \%$ of the set budget. The absorption of the expenditure budget was even higher in the 2019 fiscal year which reached $101.63 \%$. In the 2020 fiscal year when the Covid-19 Pandemic was enforced, the realization of the Kediri City Government expenditure was IDR $1,207,691,60,980,-$ from the budgeted expenditure of IDR 1,424,625,920,381,-. So in the 2020 fiscal year, when the Covid-19 Pandemic occurred, the absorption of the Kediri City Government's budget was only
$84.77 \%$. This budget absorption is the lowest compared to previous years.

\section{Expenditure growth analysis}

Table 6 shows that the growth of Kediri City Government expenditure during the last four years has fluctuated. The realization of expenditure in the 2018 fiscal year was IDR $1,237,745,256,863$, this amount was lower than the 2017 fiscal year which reached IDR 1,269,944,308,580,which means a decrease of $3 \%$ (or minus $3 \%$ growth). In the 2019 budget year, the realization of expenditure reached IDR $1,312,905,390,345$, - which means that the Kediri City Government expenditure in the 2019 fiscal year grew by $6 \%$. In 2020, the realized expenditure was IDR $1,207,691,610,980,-$ which is lower compared to 2019. Thus, in 2020, the growth of Kediri City Government expenditure grew minus $8.00 \%(-8.00 \%)$.

\section{Expenditure efficiency analysis}

The results of the calculations as shown in table 6 also show that the performance of the Kediri City Government in terms of expenditure efficiency for the last four years, from 2017 to 2020 has shown an efficient performance. The realization of the budget for the last four years showed an average figure of $94.30 \%$. Fiscal year 2017 there was an efficiency of IDR 73,060,915,138,-because the realization of expenditure was lower than budgeted. In 2018 the budgeted expenditure was IDR 1,286,436,587,918, - while the realization was IDR $1,237,745,256,863$, - so there was an efficiency of 48,691,331,055,-. As well, in 2020 there was an efficiency of expenditure of IDR 216,934,309,401,because the total budgeted expenditure was IDR 1,424,625,920,381,- and the realization of expenditure was IDR 1,207,691,610,980,-.Expenditure 
inefficiency occurred in the 2019 fiscal year amounting to IDR 21,114,056,745, $(1.63 \%)$. This year, the realization of expenditures amounted to IDR $1,312,905,390,345$, - exceeding the budget set at IDR 1,291,791,333,600.

\section{Expenditure Compatibility Analysis}

Table 7 shows that in 2017, 2018, and 2020 fiscal years, the Kediri City Government allocated its budget in its APBD mostly for indirect expenditures, which consisted of personnel expenditures, grants, and social assistance, and the rest was allocated for direct expenditures consisting of expenditure on goods and services, and capital expenditure. In the last four years, the Government of Kediri City has allocated an average of $55 \%$ of expenditure in APBD and $45 \%$ of the expenditure is allocated for direct expenditure. In 2017, indirect spending reached IDR 673,80,39,069 (53\%), and in 2018 it increased to $59 \%$ of total expenditure, which was IDR $730,579,986,292$. In 2020 , the portion of indirect expenditure was $53 \%$ of total spending. However, the allocation of expenditure in 2019 was greater for direct expenditure compared to indirect expenditure, reported 54\%:46\%. Direct expenditures in 2019 amounted to IDR $714,561,995,870$, - consisting of goods and services expenditures of IDR 353,568,431, 385.26 and capital expenditures of IDR $243,195,558,126.48$. During the last four years personnel expenditure was the largest portion of expenditure. The average personnel expenditure reaches $43 \%$ of total expenditure, or reaches $80 \%$ of the total indirect expenditure in the APBD structure.

\section{Financing analysis}

Table 8 shows that the Remaining Budget Financing (SilPA) has relatively increased from year to year, and only in 2018 the number of SiLPA decreased compared to the previous year. For the 2019 fiscal year, the number of SiLPAs reached IDR 20,839,243,934,- or an increase of $20 \%$ from SiLPAs in 2018. The SiLPAs for the
2020 fiscal year increased to IDR $267,341,428,526$, or $11 \%$ of the SiLPA in 2019 of IDR $240,839,243,934$,-

\section{CONCLUSION}

Based on the data analysis as described previously, it can be concluded that: (1) the budget performance of the Kediri City Government in terms of revenue variance is categorized as good, this is indicated by the realization of income that exceeds the set target. In 2020, although the realization of revenue could exceed the target, the percentage of revenue decreased compared to previous years, (2) as a result of the Covid-19 Pandemic, the revenue of the Kediri city in the 2020 fiscal year experienced a negative growth of $4.2 \%$., ( 3 ) the budget performance of the Kediri City Government from 2017 to 2020 in the aspect of financial independence is categorized as very low, (4) the realization of regional tax revenues and regional levies exceeds the targets set in APBD, and the performance of the Kediri City Government in the aspect of the effectiveness of local tax collection and regional levies are in the very effective category, (5) the performance of the Kediri City Government in collecting revenue in the form of regional taxes and regional levies is categorized as efficient, (6) in the 2020 fiscal year, when the Covid19 Pandemic occurs, the absorption of the Kediri City Government's budget is the lowest compared to previous years (7). The 2020 budget year the growth of the Kediri City Government expenditure grew minus $8.00 \%(-8.00 \%)$ compared to the previous year, (8) the performance of the Kediri City Government in terms of expenditure efficiency for the last four years, as found from 2017 to 2020 has shown an efficient performance, (9) the Government of Kediri City allocates the budget in its APBD mostly for indirect expenditure (an average of 55\%), which consists of personnel expenditure, grants, and social assistance, and the rest was allocated for direct expenditures (an average of $45 \%$ ) which consists of goods and services expenditures, 
and capital expenditures, (10) the SiLPA for the 2020 fiscal year has increased by $11 \%$ from the SiLPA in the previous year.

\section{Acknowledgement: None}

\section{Conflict of Interest: None}

\section{Source of Funding: None}

\section{REFERENCES}

1. Peraturan Walikota (PERWALI) tentang perubahan kedelapan atas peraturan walikota kediri nomor 39 tahun 2019 tentang penjabaran anggaran pendapatan dan belanja daerah tahun anggaran 2020. 2020.

2. Peraturan Daerah (PERDA) tentang Perubahan Anggaran Pendapatan Dan Belanja Daerah Tahun Anggaran 2020. 2020.

3. M. Anas, "Pengaruh Good Public Governance (Gpg ) Terhadap Kualitas Informasi Laporan Keuangan Pemerintahan Desa di Kabupaten Kediri," JAE J. Akunt. dan Ekon., vol. 6, no. 1, pp. 132-142, 2021.

4. M. Anas, "Peran Sistem Pengendalian Internal Dalam Meningkatkan Akuntabilitas Pengelolaan Anggaran Pendapatan dan Belanja Desa di Kabupaten Kediri," in Seminar Nasional Manajemen, Ekonomi dan Akuntasi Fakultas Ekonomi dan Bisnis UNP Kediri, 2020, no. September, pp. 318-329.

5. A. Suyitno, "Dampak Pandemi Terhadap Penyerapan Anggaran di Kantor Kementerian Agama Kabupaten Mojokerto," J. Public Policy, vol. 6, no. 2, p. 67, 2020.

6. Y. M. Basri, "Pengelolaan Keuangan Pemerintah di Masa Pandemi Covid 19 (Kasus Pada Pemerintah Provinsi Riau)," vol. 4, no. 1, pp. 33-48, 2021.

7. K. R. A. P. Elizar Sinambela1, "Analisis Kinerja Anggaran Pendapatan Dan Belanja Daerah Pada Pemerintah Provinsi Sumatera Utara," J. Ris. Akunt. Bisnis, vol. 53, no. 9, pp. 1689-1699, 2016.

8. I. Bastian, Akuntansi Sektor Publik: Suatu Pengantar, 3rd ed. Jakarta: Erlangga, 2010.
9. M. S. K. Adul Halim, Akuntansi Keuangan Daerah, 4th ed. Jakarta: Salemba Empat, 2012.

10. R. Perwita Sari, H. Tjahjono, P. Na-sional Veteran Jawa Timur, R. Rungkut Madya, and J. Timur, "Analysis Of Financial Performance In Public Sector (A Case Study in Lamongan, East Java-Indonesia)," JASF J. Account. Strateg. Financ., vol. 1, no. 1, pp. 82-90, 2018.

11. KASP, Standar Akuntansi Pemerintahan. Indonesia, 2019.

12. A. Labi, "Analisis kinerja anggaran pendapatan dan belanja daerah pada pemerintah daerah kabupaten pulau morotai tahun anggaran 2013-2015," J. Akunt. Bisnis dan Ekon., vol. 5, no. 1, pp. 1355-1370, 2019.

13. P. Nugroho, "Analisis atas kemandirian pemda dalam mengelola keuangannya," J. Info Arta, vol. 5, pp. 105-118, 2016.

14. A. Rante, M. S. Mire, and A. Paminto, "Analisis kemandirian keuangan daerah," INOVASI, vol. 13, no. 2, pp. 92-103, 2017.

15. I. T. Ritonga, C. Clark, and G. Wickremasinghe, "Factors Affecting Financial Condition of Local Government in Indonesia," J. Account. Invest., vol. 20, no. 2, pp. 1-25, 2019.

16. A. Yushkov, "Fiscal decentralization and regional economic growth: Theory, empirics, and the Russian experience ${ }^{\wedge}$, , Russ. J. Econ., vol. 1, no. 4, pp. 404-418, 2015.

17. W. R. Gall, M, D., Gall, J. P., \& Borg, "Educational Research an Introduction .," Br. J. Educ. Stud., vol. 1, no. 1, pp. 772-781, 2013.

18. A. Djamhuri and Mahmudi, New Public Management, Accounting Reform, and Institutional Perspective of Public Sector Accounting in Indonesia, vol. 8, no. 3. 2006, pp. 301-321.

How to cite this article: M. Anas, Linawati, Eunike Rose Mita Lukiani. The impact of the COVID-19 pandemic on the budget performance of the Kediri City Government. International Journal of Research and Review. 2022; 9(1): 412422. DOI: https://doi.org/10.52403/ijrr.20220148 